\title{
Characterization of Waste Tire Pyrolysis Products by GC, ICP-MS, TGA and DSC
}

\author{
Gediz UĞUZ1 ${ }^{1}$, Abdülkadir AYANOĞLU²* \\ ${ }^{1}$ Ondokuz Mayls Üniversity, Engineering Faculty, Department of Chemical Engineering, Samsun, Turkey \\ ${ }^{2}$ Mardin Artuklu University, Vocational School, Department of Machinery and Metal Technologies, Mardin, \\ Turkey \\ (ORCID: 0000-0002-6796-6067) (ORCID: 0000-0002-5835-558X)
}

\begin{abstract}
The huge amount of waste tires (WTs) have been disposed to surroundings which cause dangerous effect on nature. Owing to recycled WTs, the pyrolysis is a good technique to dismiss harmful effect of the WTs, by converting into gas, liquid and solid. The present study has two steps of liquefaction at a batch reactor. Firstly, conversion of the WTs into gas, waste tire oil (WTO) and char. Then the WTO were blended with calcium oxide $(\mathrm{CaO})$ or natural zeolite (NZ) at different ratio and pyrolyzed to obtain high quality oil, similar to gasoline fuel (GF) or diesel fuel (DF). The distillation curve is a good key to define fuel quaility. Thus, $10 \% \mathrm{CaO}-\mathrm{WTO}$ blend curve near to the DF. Unfortunately, the mixture was distillated at $54{ }^{\circ} \mathrm{C}$, lower than the DF. Therefore, the blend was separated into two fractions due to intial-final boiling points as $150{ }^{\circ} \mathrm{C}$ to $360{ }^{\circ} \mathrm{C}$, named as Diesel like fuel (DLF); between $54{ }^{\circ} \mathrm{C}$ to 150 ${ }^{\circ} \mathrm{C}$, called as gasoline like fuel (GLF). Finally, samples were analyzed to characterizate by GC, ICP-MS, TGA and DSC for similarities of conventional fuels. The heavy metals and other elements of samples were analyzed by ICP-MS techniques. TGA is a good test to determine the oxidative and thermal stabilities of fuel while DSC was used to determine crystallization onset temperature on fuel samples. GC analysis is done for detemening of gas heating value and beside gas contents which has a comprehensive with standard burnable gas. Based on GLF and DLF with unliquified gas results, all of components of products can be burned in engine without any problem.
\end{abstract}

Keywords: Waste Tire, Pyrolysis, Gasoline Like Fuel, Diesel Like Fuel, Characterization

\section{Atık Lastik Piroliz Ürünlerinin GC, ICP-MS, TGA ve DSC tarafından karakterizasyon}

\begin{abstract}
Öz
Büyük miktarda atık lastik (AL) çevreye atılmakta ve doğa üzerinde tehlikeli etkilere sebep olmaktadır. AL'in geri donuşumu için, piroliz kullanılarak atık lastiklerin gaz, sıvı ve katı ürünlere dönüştürülerek AL'nin zararlı etkilerini bertaraf etmek amacıyla kullanılan etkili bir tekniktir. Bu çalışmada, bir kesikli reaktör kullanılarak iki adımda sıvılaştırma yapılmıştır. İlk olarak, atık lastik gaza, atık lastik yağına (ALY) ve karbon siyahına dönüştürülmüştür. İkinci adımda ise ALY, farklı oranda Kalsiyum Oksit $(\mathrm{CaO})$ veya Doğal Zeolit (NZ) ile karıştırılarak; benzine veya dizel benzeyen yakıt yüksek kaliteli yakıt elde etmek için piroliz edilmiştir. Distilasyon eğrisi, yakıt kalitesini tanımlamak için iyi bir referanstır. \% 10CaO-ALY karışımının distilasyon eğrisi dizel yakıta benzerlik gösterdiği tespit edilmiştir. Fakat karışımın dizel yakıttan daha düşük olan $54{ }^{\circ} \mathrm{C}$ 'de distile edilmiştir. Bu nedenle karışım, ilk-son kaynama noktalarına göre ayrıştırılarak iki fraksiyon elde edilmiştir. $54{ }^{\circ} \mathrm{C}$ ile $150{ }^{\circ} \mathrm{C}$ arasında, benzin benzeri yakıt (BBY); $150{ }^{\circ} \mathrm{C}$ ile $360^{\circ} \mathrm{C}$ arasında dizel benzeri yakıt (DBY)) elde edilmiştir. Elde edilen bu iki fraksiyon, geleneksel yakıtlara benzerliklerini değerlendirmek amacıyla GC, ICP-MS, TGA ve DSC teknikleri kullanılarak analiz edilmiştir. Örneklerdeki ağır metaller ve diğer elementler ICP-MS tekniği ile analiz edilmiştir. TGA yakıtlardaki termal ve oksidasyon kararlılığını belirlemek için kullanılan iyi bir tekniktir. DSC ise yakıt örneklerindeki kristallenmeye başladığı noktanın belirlenmesi amacıyla kullanılmıştır. GC analizi ile gazin 1sıl değeri tespit edilip, bununla beraber gaz içeriği de tespit edilerek standard yanabilen gazlarla karşılastıtılmıştır.

Elde edilen sonuçlar BBY ve DBY ile sıvılaşmayan gaz numune sonuçlarının motorlarda problemsiz kullanılabileceğini göstermiştir.
\end{abstract}

Anahtar Kelimeler: Atık Lastik, Piroliz, Benzin Benzeri Yakıt, Dizel Benzeri Yakıt, Karakterizasyon

"Corresponding author: a.ayanoglu1@gmail.com

Received: 13.12.2020, Accepted: 01.09.2021 


\section{Introduction}

The continuity of world has been sustained by traditional energy source however energy needs increase and standard energy resource decrease by social and politicrpcal statements. [1,2]. Therefore, plentiful resources have been to supplied instead of petreloum fuels such as waste tires, waste agriculture and etc. Some of researchers have noticed that waste material (WM) has recovered to use in broad industrial applications. [3, 4]. Due to the WTs statistics of world, about 17 million tonnes were produced in a year [5]. The China discarded one third of produced tire as approximately 5.2 million tons annually [6].

In past decades, novel technologies have been developed to produce more or less products (gas, liquid, and solid) of the WTs [7]. Pyrolysis is an impression and interesting method which can be obtained high yield products with low sulfur and less nitrogen oxides ingredients in order to decompose tire polymers under high temperature at various mediums $[8,9]$.

Several pyrolysis types such as fixed-bed (batch), screw kiln, rotary kiln, vacuum and fluidised-bed reactors have been used for recycling materials. The target of reactor for obtaining more amount of gas or liquid or solid products according to rate of heat. Therefore, the WTs were liqufied at batch reactor for more oil amount. Furthermore, this reactor have widely used because of its simple structure and easily established with low investment [10,11]. Since 1990s, many studies have been done by different operation conditions of pyrolysis [12].

Ayanoglu and Yumrutas worked on the WTs conversion by adding various ratio of $\mathrm{CaO}$ for obtaining high amount of oil with low sulfur. The WTO were analyzed by chemical and physical tests to compare with standard fuels [13].

Alkhatibet. al. [14] pyrolyzed the WTs at different powers $(750 \mathrm{~W}, 1500 \mathrm{~W}$ and $3000 \mathrm{~W})$ at reactor temperature of $500{ }^{\circ} \mathrm{C}$. The liquids amount for both $1500 \mathrm{~W}$ and $3000 \mathrm{~W}$ were higher than $750 \mathrm{~W}$ as $45 \%$ and $40 \%$, respectively. Additionly, characteristic of liquids was similar to standard fuels.

Islam et. al. [15] worked on new application of pyrolysis by using the WTs $\left(4 \mathrm{~cm}^{3}\right.$ particle size) in a fixed-bed fire-tube under nitrogen gas at $475^{\circ} \mathrm{C}$. The oil properties were tested by elemental analysis, FT-IR, ${ }^{1} \mathrm{H}-\mathrm{NMR}$ and GC-MS and distillation tests.

The test results gave an idea to use oil as fuel. The main goal of the study is to find similarity of DLF and GLF with GF and DF whether can be combusted in engine or not. For this reason, a detail analysis was done for WTO, DLF, GLF, GF and DF characterization in order to define organic compounds by GC, ICP-MS and FT-IR, techniques. Based on analytical tests, GLF and DLF approved to use as fuels.

\section{Material and Methods}

\subsection{Raw Material}

The WTs were supplied from Kudret Inkar Co., Adiyaman/TURKEY [16]. The metal and textile parts of the WTs were seperated and further washed by water to remove other non-purities and dust, then cut in $1 \mathrm{~mm}$ particle size. Finally, the WTs were dried at solar to remove waters. The procedure of the WTs pyrolysis was simplified and shown at Figure 1. 


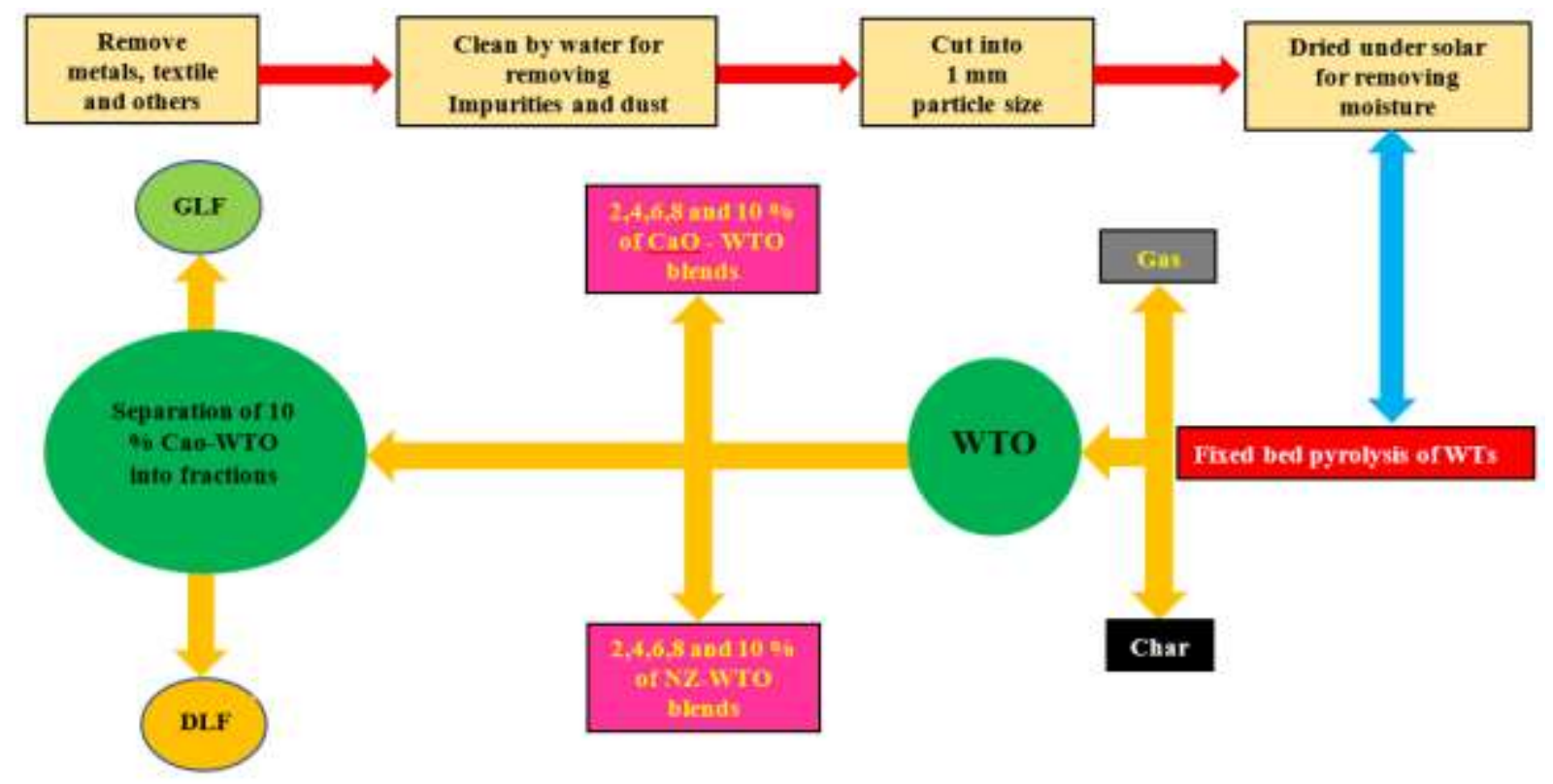

Figure 1. Procedure of the WTs pyrolysis.

\subsection{Pyrolysis System}

The fixed-bed pyrolysis system was equipped by reactor, control panel, thermocouple, blender, safety valve, heat exchanger and can. The reactor has a dimension $630 \mathrm{x} 40 \mathrm{~cm}$ with $5 \mathrm{~cm}$ glass wool isolation and $5 \mathrm{~kW}$ heater. In addition to reactor, the blender was used for homogenoues temperature distribution and the thermocouple used to measure temperature which were inserted on middle of the reactor, which was shown at Figure 2.

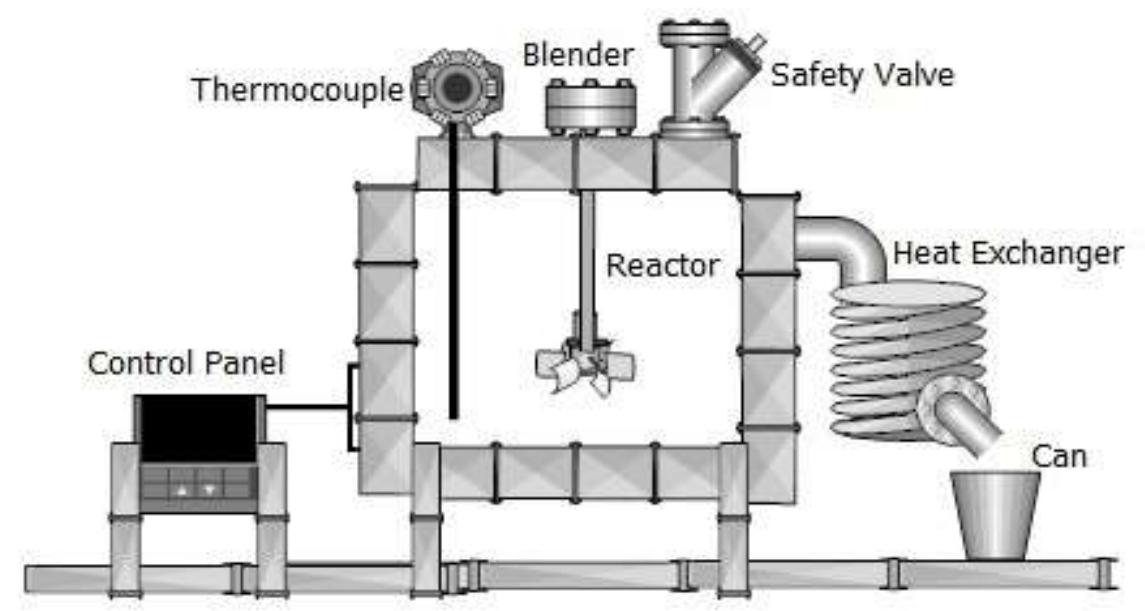

Figure 2. The pyrolysis system.

\subsection{Pyrolysis Procedure}

Furthermore, the pyrolysis has other contribution to decrease residual of solid by increase condensable (oil) and non-condensable (gas) fractions due to heating rates, catalysts, pressure and other parameters. $[10,17-20]$. The WTs have been stored to dispose or re-cycle for minimizing harmful and polluting effects because of high amount of sulfur. Particularly, sulfur has removed by preferable catalyst as $\mathrm{CaO}[21,22]$.

The WTs were pyrolyzed into gas, oil (WTO) and char at first stage of liquefaction in a fixed bed reactor by $5{ }^{\circ} \mathrm{C} / \mathrm{min}$ under atmospheric medium. Then at second stage of pyrolysis, the WTO has exposed with 2,4,6,8 and 10 mass ratios of $\mathrm{CaO}$ and $\mathrm{NZ}$ under concurrent consistence, individually. The curve of distillation test is a good key to define fuel quaility and similarities of chemicals. Thus, 
the mixture of $10 \% \mathrm{CaO}$-WTO distillation had a good curve, near to the DF. Unfortunately, the mixture was distillated from lower temperature than the DF. Therefore, the mixture was necessary required to separated into fractions due to start temperature point of the DF which was $150{ }^{\circ} \mathrm{C}$ to end temperature point of $360{ }^{\circ} \mathrm{C}$ which was heavy part, named as Diesel like fuel (DLF). The remain liquid was distilled between $54{ }^{\circ} \mathrm{C}$ to $150{ }^{\circ} \mathrm{C}$ which was light part, called as gasoline like fuel (GLF), explained in detail in previous study [13, 23].

\subsection{Statistical Analysis}

The statistical analysis was used to perfom by IBM SPSS Statistics 20 package program. The general application of program was used to predict (observed) or expected (measurement) data. The SPSS analysis is particularly used to determine sensivity and accuarcy of pyrolysis test.

\subsection{The Gas Chromotography (GC)}

The pyrolysis gas products were analyzed by Agilent GC-7890 which provided with one flame ionization detector (FID) and two thermal conductivity detector (TCD) for finding $\mathrm{C}_{1}-\mathrm{C}_{5}$ hydrocarbons, $\mathrm{C}_{6} / \mathrm{C}^{+}$hydrocarbons, $\mathrm{CO}_{2}, \mathrm{~N}_{2}$ and $\mathrm{H}_{2}$. The Gas chromotography (GC) has a $1 \mu \mathrm{m}$ Carboxen, 5 packed column with 3 capillery column and a carrier gas of Helium by $30 \mathrm{ml} / \mathrm{min}$.

The sample was injected from tedlar-bag to GC. The initial temperature of oven was $60{ }^{\circ} \mathrm{C}$ (hold 1 minute), heated up to $80^{\circ} \mathrm{C}$ by $20^{\circ} \mathrm{C} / \mathrm{min}$ then increased to $190{ }^{\circ} \mathrm{C}$ (hold 1.333 minute) by a heating rate of $30{ }^{\circ} \mathrm{C} / \mathrm{min}$ then reached to $200{ }^{\circ} \mathrm{C}$. The total analysis duration was 7 minutes. The results were determined by volumetric ratio of percentages.

\subsection{Inductively Coupled Plasma Mass Spectroscopy (ICP-MS)}

During combustion, some unburned-hydrocarbon, particles and emission gasses have been released to cause green gas effect and destroy atmosphere and enviroment. Due to the harmful exhaust effect, livers have been breathed which have damaged the respiratory system. The heavy metals have to constrain in a range for world life [24].

The heavy metals and other elements have analyzed by Inductively coupled plasma Mass Spectroscopy (ICP-MS) or Inductively coupled plasma atomic emission spectroscopy (ICP-OES) or Flame atomic absorption spectroscopy (Flame AAS) or Graphite furnace atomic absorption spectroscopy (GF-AAS) instrumentals in open literature. Due to analytical techniques, the ICP-MS has one of the excellent detection and give the best results in a short period with designated limits [25]. The heavy metal concentrations of aluminum (Al), arsenic (As), Cadmium (Cd), cobalt (Co), Chromium $(\mathrm{Cr})$, copper $(\mathrm{Cu})$, iron $(\mathrm{Fe})$, nickel $(\mathrm{Ni})$, lead $(\mathrm{Pb})$ and zinc $(\mathrm{Zn})$ were detected by Agelan 7700A ICP-MS. The latte, sample $(20 \mu \mathrm{g} / \mathrm{L})$ was mixed to homogenize with nitric acid and hydrogen peroxide $\left(\mathrm{HNO}_{3}+\mathrm{H}_{2} \mathrm{O}_{2}, 1: 1\right.$ ratio) for $1 \mathrm{~min}$., then inserted into a pressure-resistant polytetrafluoroethylene (PTFE) vessel. Finally, the microwave digestion system (Milestone Ethos D, Sorisole, Italy) was run at a temperature of $100{ }^{\circ} \mathrm{C}$ and hold $10 \mathrm{~min}$. under $300 \mathrm{ml} / \mathrm{min}$ flow rate, then leave to cool room temperature in $60 \mathrm{~min}$.

\subsection{Thermogravimetric Analysis (TGA)}

The fuel chemical stability defines ability of any fuel which has resistance to oxidation and chemical changes for long-time storage or long-term shipping. The main point of stability of chemical is related with unsaturated hydrocarbons of fuel which can be a reason for rise propensity of oxidation.

On the other hand, the olefin molecule is branched to react as a double bond from its midpoint which are caused to decrease stability of oxidation. The double bonds of hydrocarbons (dienes) have a distantance from other compounds which are behaved like olefins in therms of oxidation stability.

The unsaturated hydrocarbons are oxidized to produce resinous materials under the effect of air and temperatures [1]. At the first stage of hydrocarbon oxidation were fastly occured by hydroperoxidesunstable compositions interaction in different oxidation conditions. The hydroperoxides basicly reacts with noticeable alcohols (aldehydes, ketones and acids forms) at low temperatures during oxidation of 
hydrocarbon fuels and define storage characteristic. The hydroperoxides of unsaturated hydrocarbons can be polymerize and react with other chemicals which give a start to form resin particles. [26].

Thermogravimetric analysis (TGA) was done to determine esters and oils by temperature rise under the medium of nitrogen or argon or oxygen or dry air, etc. with mass changes due to time control. According to decomposition or oxidation or dehydration, the substance can be defined by changes of phase and mass with structures correlation. Furthermore, TGA is a good test to determine the oxidative and thermal stabilities of fuel [27-28].

In this study, the thermogravimetric (TG) thermograms of samples were tested by Shimadzu DTG $60 \mathrm{H}$ thermogravimetric analyzer [29]. A $10 \mathrm{mg}$ was weighed to put into platinum pan and analyzed under $100 \mathrm{ml} / \mathrm{min}$ dry air to determine the oxidative stability by temperature rise from $25{ }^{\circ} \mathrm{C}$ to $700{ }^{\circ} \mathrm{C}$ with a heat rate of $10{ }^{\circ} \mathrm{C} / \mathrm{min}$ for $1 \mathrm{~h}[27,29]$. Finally, the chemical reactions were completed at $700{ }^{\circ} \mathrm{C}$ due to mass stability [30]. The TGA curves were also used to define the onset temperature of samples.

\subsection{Differential Scanning Calorimetry (DSC)}

The petroleum based fuels have non-simple compounds which are known from organic chemistry (paraffin, naphthenic and aromatic hydrocarbons, sulfur, oxygen, and nitrogen) [31]. The fuel has high freezing point due to long chain of paraffin compositions. Besides, a small amount water is dissolved in fuel which can be a crystallization at low temperature, due to crystallization of water, it has an abrasive effect on fuel system [32].

The wax appearance temperature (WAT) can be defined as crystallization onset temperature. The WAT can be also obtained by ultrasonic waves differential scanning calorimetry (DSC) and crosspolarized microscopy $(\mathrm{CPM})$ with rheometry. The crystallization onset temperature $\left(\mathrm{T}_{\text {c-onset }}\right)$ is observed from heat-profile changes in which temperature starts to decrease during cooling process [33, 34]. The present work focus on crystallization onset temperature of WTO, GLF and DLF by DSC to find similarity with standard fuels. The Mettler-Toledo DSC 1700 were run under Nitrogen gas with $50 \mathrm{~mL} / \mathrm{min}$ and $8.0 \pm 1.0 \mathrm{mg}$ of sample weigh in aluminum pan which were heated up to $20{ }^{\circ} \mathrm{C}$ or cooled to -80 at a rate of $10{ }^{\circ} \mathrm{C} / \mathrm{min}$.

\section{Results and Discussion}

\subsection{The physical properties of products}

The physical test results will be declared briefly in this section. The physical properties of the WTs and its products were analyzed in previous study of Author [13]. The elemental analysis gives an information about carbon percentages of fuels which is a good indicator for heating value. The carbon percentages of WTO were as $79.49 \%$, near to standard fuels. However, sulfur amount was too high which need to decrease by a catalyst. Furthermore, the physical properties of the WTO were determined by $830 \mathrm{~kg} / \mathrm{m}^{3}$ (density), $3.21 \mathrm{~mm}^{2} / \mathrm{s}$ (viscosity), $28.1{ }^{\circ} \mathrm{C}$ (flash point), and Higher Heatin Value (HHV) as $41,00 \mathrm{~kJ} / \mathrm{kg}$. Additionally, Distillation temperature at $250{ }^{\circ} \mathrm{C}$ (max. vol.) and $350^{\circ} \mathrm{C}$ (min. vol.) were as $60 \%$ and $80 \%$. Due to the phyical properties of WTO, the WTO had similarity to DF except flash point [13].

Thus, the properties of WTO have to upgrade with a catalyst such as $\mathrm{CaO}$ and NZ, which were used in a ratio of 2 to 10 , by a step of 2 . The distillation curves of mixture were given an idea for best result which was $10 \% \mathrm{CaO}-\mathrm{WTO}$ blend. Then, the $10 \% \mathrm{CaO}-\mathrm{WTO}$ mixture were seperated into fractions by temperature differences as $54{ }^{\circ} \mathrm{C}-150{ }^{\circ} \mathrm{C}$ which named as GLF and $150{ }^{\circ} \mathrm{C}-360{ }^{\circ} \mathrm{C}$ which called DLF [13]. The elemental analysis result of carbon for GLF and DLF were as $80.44 \%$ and $81.31 \%$. However, the sulfur of DLF was too high again, that a desulfirazation process will be required. Moreover, density, flash point, and HHV of GLF and DLF were such as 740 and $825 \mathrm{~kg} / \mathrm{m}^{3}, 20$ and $130{ }^{\circ} \mathrm{C}$, and 42,163 and $43,214 \mathrm{~kJ} / \mathrm{kg}$. And also, the viscosity of DLF was $3.09 \mathrm{~mm}^{2} / \mathrm{s}$. The Initial Boiling Point (IBP), 10 vol., 50 vol. and 90 vol. of GLF distillation results were as 54\%, $74 \%, 121 \%$ and $188 \%$. Besides, distillation temperature of DLF for $250^{\circ} \mathrm{C}$ (max.vol.) and $350^{\circ} \mathrm{C}$ (min. vol.) were as $50 \%$ and $95 \%$ [13]. As a conclusion, GLF and DLF physical properties were close to convetional fuels which can be burned in engines. 
The high amount carbon content as $\mathrm{C}_{1}, \mathrm{C}_{2}, \mathrm{C}_{3}, \mathrm{C}_{4}$ and $\mathrm{C}_{6}$ compounds were suitable to burn in heating systems $[35,36]$. The non-condensable gases of Wts can be burned directly or react with catalyst to upgrade gas quality [37-38], while pyrolysis gases are generally combusted. On the other hand, the gas has available ingredients which can be produced by thermochemical methods and developed economy [39-40].

Non-condensable gas was tested due to Turkish Standarts Instutition standard (TSE K-13). Outlet volumetric flow rate of the gas from reactor was $204 \mathrm{~m}^{3} / \mathrm{s}$. The condensable gas composition and heating value results have been changed due to heating rate, reactor types, raw material sizes and catalyst usage. The composition of gas products from pyrolysis were shown at Table 1. According to volumetric real gas, volumetric real gas, molar and mass of HHV and LHV of pyrolysis gas at $20{ }^{\circ} \mathrm{C}$ and $1 \mathrm{~atm}$ condtions were displayed at Table 2. The LHV was defined as $40.23 \mathrm{MJ} / \mathrm{kg}$ due to mass, was close to standard petreloum fuels.

Table 1. The composition of gas products from pyrolysis.

\begin{tabular}{ccc}
\hline Composition & $\begin{array}{c}\text { Avarage } \\
\text { Concentrations } \\
\text { (vol\%) }\end{array}$ & $\begin{array}{c}\text { Avarage } \\
\text { Concentrations } \\
\text { (vol\%) }\end{array}$ \\
\hline $\mathrm{CO}_{2}$ & 9.972 & $<25$ \\
$\mathrm{~N}_{2}$ & 0.880 & $<45$ \\
$\mathrm{O}_{2}$ & 0.291 & $<6.5$ \\
$\mathrm{CO}$ & 2.847 & --- \\
$\mathrm{H}_{2}$ & 8.846 & --- \\
Methane & 20.235 & $<50$ \\
Ethane & 5.820 & $<10$ \\
Ethylene & 10.714 & --- \\
Propane & 3.392 & $<7.0$ \\
Propylene & 5.416 & --- \\
i-buthane & 1.457 & $<3.5$ \\
n-buthane & 0.611 & $>0.35$ \\
1-buthane & 0.810 & --- \\
t-2-buthane & 1.011 & --- \\
iso-buthane & 14.287 & --- \\
c-2-buthane & 0.885 & --- \\
n-hexane & 12.526 & $<6$ \\
\hline
\end{tabular}

Table 2. The HHV and LHV of pyrolysis gas at $20^{\circ} \mathrm{C}$ and 1 atm condtions.

\begin{tabular}{rcccc}
\hline & \multicolumn{2}{c}{$\mathbf{H H V}$} & \multicolumn{2}{c}{$\mathbf{L H V}$} \\
\cline { 2 - 5 } Volumetric ideal gas & $\mathbf{M J} / \mathbf{m}^{\mathbf{3}}$ & $\mathbf{k c a l} / \mathbf{m}^{\mathbf{3}}$ & $\mathbf{M J} / \mathbf{m}^{\mathbf{3}}$ & $\mathbf{k c a l} / \mathbf{m}^{\mathbf{3}}$ \\
\cline { 2 - 5 } Volumetric real gas & 71.56 & 17104 & 66.25 & 15834 \\
& 72.45 & 17317 & 67.07 & 16031 \\
\cline { 2 - 5 } Molar & $\mathbf{k j} / \mathbf{m o l}$ & $\mathbf{k c a l} / \mathbf{m o l}$ & $\mathbf{~ k j} / \mathbf{m o l}$ & $\mathbf{~ k c a l} / \mathbf{m o l}$ \\
\cline { 2 - 5 } & 1868.15 & 446.50 & 1593.59 & 380.88 \\
\cline { 2 - 5 } & $\mathbf{M J} / \mathbf{k g}$ & $\mathbf{k c a l} / \mathbf{k g}$ & $\mathbf{M J} / \mathbf{k g}$ & $\mathbf{k c a l} / \mathbf{k g}$ \\
\cline { 2 - 5 } Mass & 47.17 & 11273 & 40.23 & 9616 \\
\hline
\end{tabular}




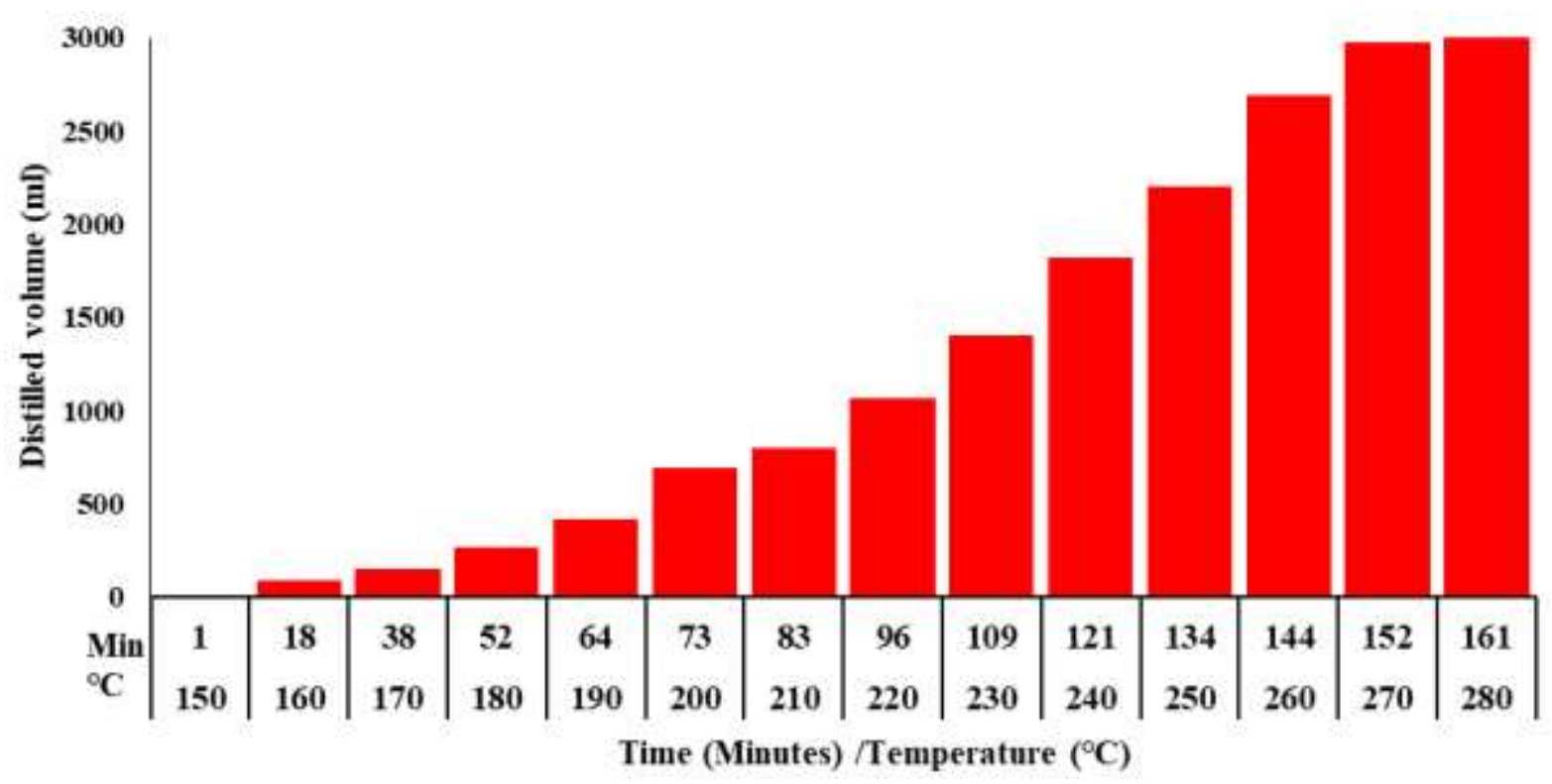

Figure 3. The distilation of GLF changes with time.

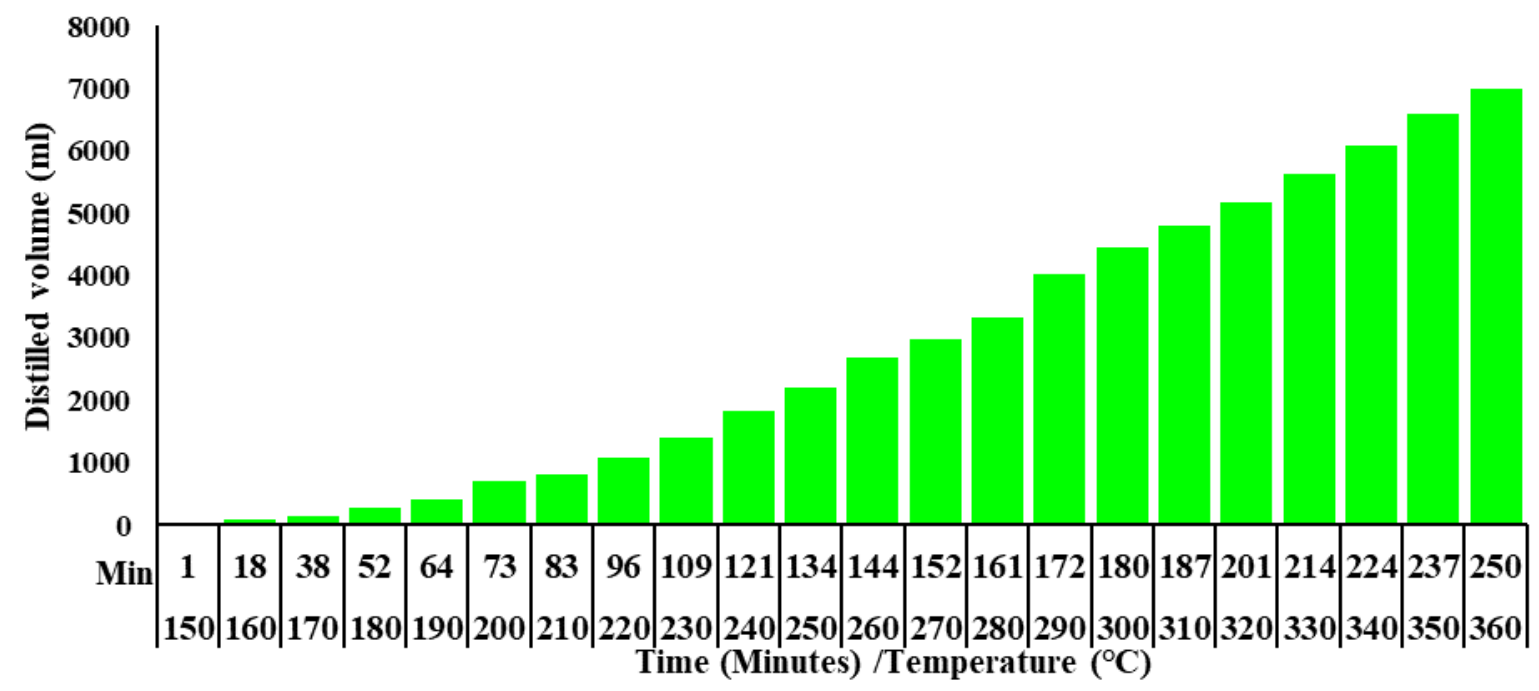

Figure 4. The distilation of DLF changes with time.

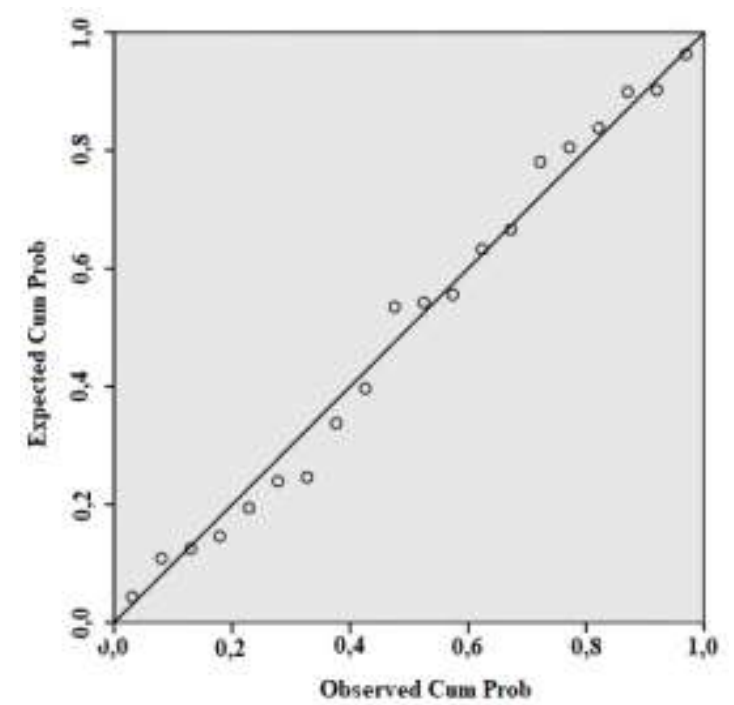

Figure 5. The SPSS analysis of $10 \% \mathrm{CaO}-\mathrm{WTO}$ mixture at distilation system 
The conventional distillation test uses to define hydrocarbon boiling temperature point by heating sample and also use to separate vapor and liquid phases due to temperature difference. Furthermore, the distillation test are utilized to define properties of chemical compounds and their structures which give a great estimation on perfonmances and emissions as well [41-43]. In this study, the distillation curves of GLF and DLF samples were verified with times and displayed at Figures 3 and 4.

The first fraction (GLF) of pyrolysis was started to heat up to $54{ }^{\circ} \mathrm{C}$ in 21 min to obtain first drop, then temperature increase to $150{ }^{\circ} \mathrm{C}$ in $150 \mathrm{~min}$. Afterwards, the second fraction was liqufied from $150{ }^{\circ} \mathrm{C}$ to $360{ }^{\circ} \mathrm{C}$ in a $250 \mathrm{~min}$. The temperature increase for each $5 \mathrm{~min}$. which known as heating rate. The linear correlation between time temperature were seen at Figures 3 and 4 by verifiation of distillated volume due to pyrolysis test.

By comparing distillation curve of GLF, was done due to ASTM D86, with first fraction pyrolysis of has a accuracy measured results. The pyrolysis distillation test of GLF and DLF were compared with sandard distilation test, by using a K45000 apparatus due to ASTM D86. The slope of curves were similar to conventional fuels. A statistical analysis was done to distinguish good case for reproducibility of $10 \% \mathrm{CaO}-\mathrm{WTO}$ mixture pyrolysis test. Thus, the experimential data were simulated by Regression Analysis of SPSS.

The Observed Cum Prob and Expected Cum Prob were known as experimental and training data which shown at Figure 5. By increase of distillation temperature which were cause to increase distillated volume by time. The beads were distributed around linear slope line that the pyrolysis were done in terms of accuary. The adjusted square of the correlation coefficient $\left(\mathrm{R}^{2}\right)$ was found as 0.982 , close to 1 which mean high experimental accuracy.

\subsection{Inductively Coupled Plasma Mass Spectroscopy (ICP-MS)}

The heavy metals of fuel have negative and destruction effect on engine and environment. Therefore, a restriction put on heavy metal amounts by laws. The $\mathrm{Al}, \mathrm{As}, \mathrm{Cd}, \mathrm{Co}, \mathrm{Cr}, \mathrm{Cu}, \mathrm{Fe}, \mathrm{Ni}, \mathrm{Pb}$ and $\mathrm{Zn}$ were detected and tabulated at Table 3, by assitance of microwave of ICP-MS.

The amounts $\mathrm{Fe}, \mathrm{Cd}, \mathrm{Pb}, \mathrm{Al}$ and $\mathrm{As}$ of samples were lower than standard fuels however $\mathrm{Cu}$ was close to petroleum fuels [44, 45]. As shown in Table 4, the ICP-MS results have a good agreement to literature and "Category I Waste Oil" law of Republic of Turkey (Regulation on Control of Waste Oils in Turkey). As ICP-MS test result of GLF and DLF can be burned in chamber engine without any problems for engine and have no harmfull effect on enviroment.

Table 3. ICP-MS test results of WTO, DLF, DF, GLF and GF.

\begin{tabular}{cccccc} 
Pollutants(ppm) & WTO & DLF & DF [46] & GLF & GF [46] \\
\hline $\mathrm{Al}$ & 0.595 & 0.3180 & 0.0083 & 0.3260 & 0.0014 \\
$\mathrm{As}$ & 0.590 & 0.059 & - & 0.166 & - \\
$\mathrm{Cd}$ & 0.004 & 0.0010 & 0.0064 & 0.0010 & 0.0015 \\
$\mathrm{Co}$ & 0.001 & 0.0010 & 0.0003 & $<0.100$ & 0.0002 \\
$\mathrm{Cr}$ & 0.260 & 0.0020 & 0.0080 & 0.0350 & 0.0019 \\
$\mathrm{Cu}$ & 0.274 & 23.022 & 0.0074 & 13.887 & 0.0028 \\
$\mathrm{Fe}$ & 2.401 & 0.5610 & 0.0089 & 0.7010 & 0.0100 \\
$\mathrm{Ni}$ & 1.273 & $<0.100$ & 0.0064 & $<0.100$ & 0.0019 \\
$\mathrm{~Pb}$ & 0.091 & 0.0280 & 0.0066 & 0.0220 & 0.0016 \\
$\mathrm{Zn}$ & 8.500 & 2.2440 & 0.0520 & 2.1270 & 0.2500 \\
\hline
\end{tabular}

Table 4. Turkey waste oil categories and their pollutant limit values [47].

\begin{tabular}{|c|c|c|c|}
\hline \multirow{3}{*}{$\begin{array}{c}\text { Pollutants } \\
\text { (ppm) }\end{array}$} & \multicolumn{3}{|c|}{ Allowed limit } \\
\hline & \multicolumn{3}{|c|}{ Category of waste oil } \\
\hline & I & II & III \\
\hline As & $<5$ & Max.5 & $>5$ \\
\hline $\mathrm{Cd}$ & $<2$ & Max. 2 & $>2$ \\
\hline $\mathrm{Cl}$ & Max. 200 & Max. 2000 & $>2000$ \\
\hline $\mathrm{Cr}$ & $<10$ & Max. 10 & $>10$ \\
\hline $\mathrm{Pb}$ & $<100$ & Max. 100 & $>100$ \\
\hline
\end{tabular}




\subsection{Thermogravimetric Analysis (TGA)}

The TGA and DrTGA curves of samples were indicated oxidative degradation which were happened at a range of $23.50-570.92{ }^{\circ} \mathrm{C}$ for a single continuous step. The onset degradation temperature $\left(\mathrm{T}_{\text {onset }}\right)$ inform an opinion about initial boiling point with thermal stability. The $\mathrm{T}_{\text {onset }}$ were become higher value at low polyunsaturation for maximizing of oxidation stability. Besides, the $T_{\text {onset }}$ were enhanced in a small range for more thermal stability [48]. In order to find out the combustion characteristics of samples were burned under air medium with $10^{\circ} \mathrm{C} / \mathrm{min}$. The combustion results of thermograms and derivative thermograms of samples were represented at Figures 6 and 7.

The onset and end temperatures and mass loss of samples were declared at Table 5 while Table 6 represented combustion reaction intervals, peak temperatures, and weightlosses of samples. The reaction ranges were exposed at $40.45-323.70^{\circ} \mathrm{C}, 29.15-290.14^{\circ} \mathrm{C}$ and $31.98-272.49^{\circ} \mathrm{C}$ for WTO, DLF and GLF respectively. While, the combustion thermograms of WTO, DLF, DF, GLF and GF were stated at weight loss of $99.75 \%, 99.81 \%, 99.18 \%, 98.77 \%$ and $98.46 \%$, respectively. As a comparative of DLF and GLF results were close to standard petreloum which can be acceptable as alternative fuels [28].

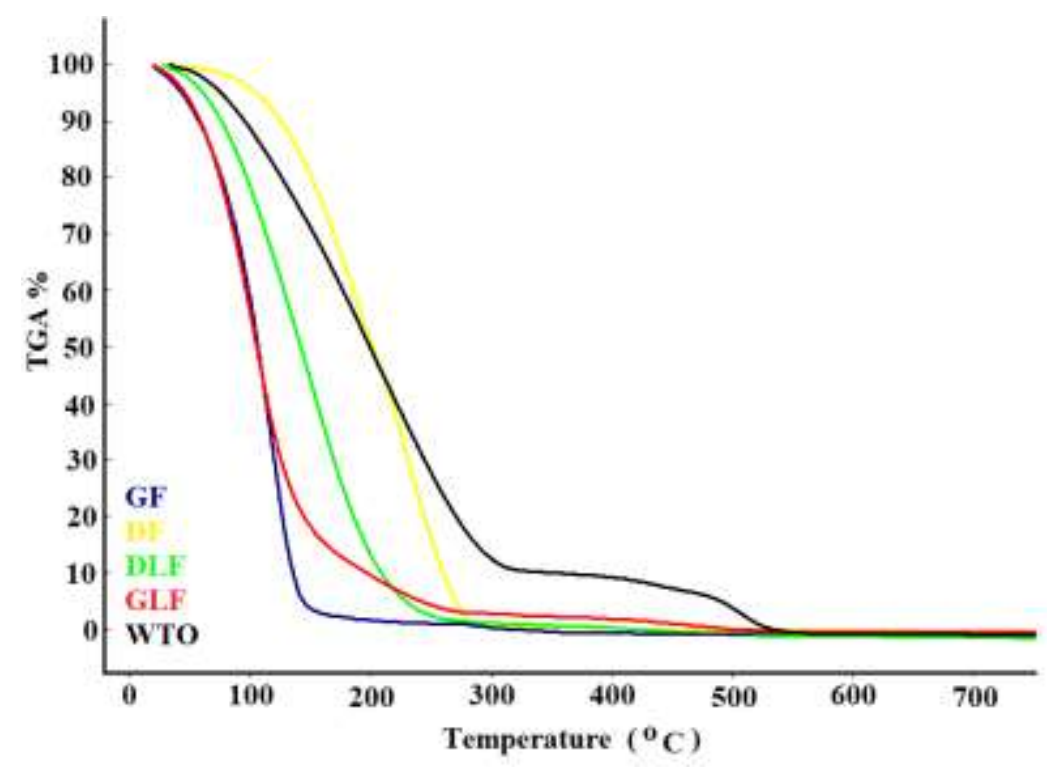

Figure 6. Thermogravimetric analyses (TGA) of WTO, DLF, DF, GLF and GF samples for oxidative stability.

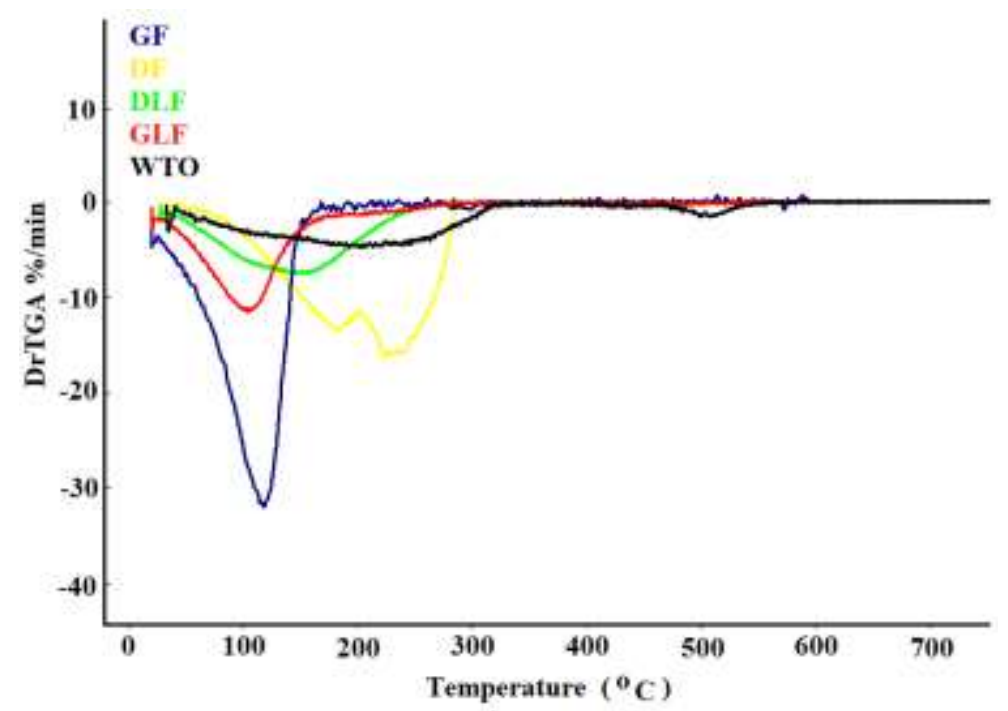

Figure 7. Derivative thermogravimetric analyses (DrTGA) of WTO, DLF, DF, GLF and GF samples for oxidative stability. 
Table 5. TGA analysis of onset and end temperatures with mass loss of samples

\begin{tabular}{lccc}
\hline Sample & $\mathbf{T}_{\text {onset }}\left({ }^{\circ} \mathrm{C}\right)$ & $\mathbf{T}_{\text {end }}\left({ }^{\circ} \mathrm{C}\right)$ & Weight loss $(\boldsymbol{\%})$ \\
\hline WTO & 34.80 & 570.92 & 99.75 \\
DLF & 28.09 & 309.15 & 99.81 \\
DF & 29.01 & 295.80 & 99.18 \\
GLF & 20.68 & 461.43 & 98.77 \\
GF & 23.50 & 137.00 & 98.46 \\
\hline
\end{tabular}

Table 6. DrTGA analysis of combustion reaction intervals, peak temperatures, and weight losses of samples

\begin{tabular}{lccc}
\hline Sample & Reaction region $\left({ }^{\circ} \mathrm{C}\right)$ & Peak temperature $\left({ }^{\circ} \mathrm{C}\right)$ & Weight loss $(\%)$ \\
\hline WTO & $40.45-323.70$ & 200.44 & 50.10 \\
DLF & $31.98-272.49$ & 149.99 & 55.85 \\
DF & $29.15-290.14$ & 224.57 & 65.33 \\
GLF & $20.68-281.26$ & 104.29 & 49.03 \\
GF & $28.09-159.12$ & 117.80 & 44.47 \\
\hline
\end{tabular}

\subsection{Differential Scanning Calorimetry (DSC) Results}

The Cloud Point (CP) has taken attention because of low crystallization temperature [49]. Due to temperature decrease, the temperature of fuel become lower than Cloud Point while, fuel stay stable for a certain time. However, after a period of time, the wax crystals were arranged to sink down slowly as layers into vessel bottom. Especially, the wax of heavy fuels were obviously watched by naked eyes $[50]$.

The crystallization onset temperatures of WTO, DLF, DF, GLF and GF were as $-47.11^{\circ} \mathrm{C}$, $21.31{ }^{\circ} \mathrm{C},-16.84{ }^{\circ} \mathrm{C},-11.31{ }^{\circ} \mathrm{C}$ and $-10.97{ }^{\circ} \mathrm{C}$, respectively which was shown at Table 7 . According to the WAT, the DLF crystallizes quicker than GLF while GF and DF have a slower crystallization than others. As a consequence, DLF and GLF can be added in to petroleum fuels for decreasing cost and enrich chemical properties of fuels.

On the other hand, cold flow properties were also decrease by changing size and shape of wax crystals at freezing points. The Cloud Point can be observed by naked eyes easily in case of huge paraffins precipition or in contrast hard to observe inversely [51]. On set crystallization temperature could be detected in an accuracy method of DSC [52].

Table 7. Crystallizations onset temperatures $\left({ }^{\circ} \mathrm{C}\right)$ of WTO, DLF, DF, GLF and GF

\begin{tabular}{lc}
\hline Sample & $\mathrm{T}_{\text {onset }}\left({ }^{\circ} \mathrm{C}\right)$ \\
\hline WTO & -47.11 \\
DLF & -21.31 \\
DF & -16.84 \\
GLF & -11.31 \\
GF & -10.97 \\
\hline
\end{tabular}

\section{Conclusions}

The WTs was converted to rich organic compounds of products by pyrolysis. Particularly, the physico-chemical properties and HHV of WTO were similar to DF. The CaO was exposed with WTO at different mass ratio to bring similarity. Then, the new products compared with diesel fuel. The $10 \% \mathrm{CaO}$-WTO mixture curve was close to DF. By temperature differences, the mixture was divided into light and heavy fractions. Both of products were too close to petroleum fuels and analyzed via GC, ICP-MS, TGA and DSC which results declared below:

1. Due to TSE K-13, the WTOs' gas compounds and calorific value (LHV=40.23 MJ/kg) had close similarity to natural gas or burnable gas. 
2. The distillation temperature via distillated volume with time were trained by IBM SPSS Statistics $20 . \mathrm{R}^{2}$ were computed as $0.982<1$, that it refers efficiency reaction in reactor in terms of maximum accuracy.

3. The ICP-MS analysis were done for such elements as $\mathrm{Al}, \mathrm{As}, \mathrm{Cd}, \mathrm{Co}, \mathrm{Cr}, \mathrm{Cu}, \mathrm{Fe}, \mathrm{Ni}$, $\mathrm{Pb}$ and $\mathrm{Zn}$ which had minimum impact on engine chamber and environment. The ICP-MS results of GLF and DLF were lower than Turkish law of "Category I Waste Oil".

4. The results of TGA for WTO show that the oxidative degradation occurred in a single continuous step in the temperature range $30-570{ }^{\circ} \mathrm{C}$ with the mass losses occur at levels of $99.75 \%$. The results of TGA for DLF, GLF, GF and DF show that the oxidative degradation occurred in a single continuous step in the temperature range $20-310{ }^{\circ} \mathrm{C}$ with the mass losses occur at levels of $99.81 \%$. The TGA, DrTGA results of GLF and DLF were compared with other fuels that can be combust in engine.

5. Due to crystallization temperature, GLF and DLF could be put in fuels for minimize cost and cold flow properties by enrich properties of chemical at freezing points.

\section{Acknowledgement}

The authors wish to thank Tuna DEMIRCİ, DÜBİT, Düzce University, Düzce, Turkey for the TGA Analysis.

\section{Author's Contributions}

All authors contributed equally to the study.

\section{Statement of Conflicts of Interest}

There is no conflict of interest among the authors.

\section{Statement of Research and Publication Ethics}

The authors declares that this study complies with Research and Publication Ethics.

\section{References}

[1] Chorazy T., Čáslavský, J., Žvaková, V., Raček, J., Hlavínek, P. 2019. Characteristics of Pyrolysis Oil as Renewable Source of Chemical Materials and Alternative Fuel from the Sewage Sludge Treatment. Waste and Biomass Valorization, 11:4491-4505.

[2] Lira H.N.F., Rangel E.T., Suarez P.A.Z. 2018. Diesel-Like Fuels and Lubricating Grease Preparation from an Industrial Oily Waste. Waste and Biomass Valorization, 9: 2459-2470.

[3] Galvagno S., Casciaro G., Casu S., Martino M., Mingazzini C., Russo A., Portofino S. 2009. Steam gasification of tyre waste, poplar, and refuse-derived fuel: A comparative analysis. Waste Manag, 29: 678-689.

[4] Vounatsos P., Atsonios K., Itskos G., Agraniotis M., Grammelis P., Kakaras E. 2016. Classification of Refuse Derived Fuel (RDF) and Model Development of a Novel Thermal Utilization Concept Through Air-Gasification. Waste and Biomass Valorization, 7:1297-1308.

[5] Cheng X., Song P., Zhao X., Peng Z., Wang S. 2018. Liquefaction of ground tire rubber at low temperature. Waste Manag, 71:301-310.

[6] Li Q., Li F., Meng A., Tan Z., Zhang Y. 2018. Thermolysis of scrap tire and rubber in sub/super-critical water. Waste Manag,71:311-319.

[7] Kyari M., Cunliffe A., Williams P.T. 2005. Characterization of oils, gases, and char in relation to the pyrolysis of different brands of scrap automotive tires. Energy and Fuels, 19:1165-1173.

[8] Lam S.S., Chase H.A. 2012. A review on waste to energy processes using microwave pyrolysis, 5: 4209-4232. 
[9] Sienkiewicz M., Kucinska-Lipka J., Janik H., Balas A. 2012. Progress in used tyres management in the European Union: A review. Waste Manag, 32: 1742-1751. Williams P.T. 2013. Pyrolysis of Waste Tyres: A review. Waste Manag. 129:109932.

[10] Williams P.T. 2013. Pyrolysis of waste tyres: A review. Waste Manag, 33:1714-1728.

[11] Xu S., Lai D., Zeng X., Zhang L., Han Z., Cheng J., Wu R., Mašek O., Xu G. 2018. Pyrolysis characteristics of waste tire particles in fixed-bed reactor with internals. Carbon Resour. Convers, 1:228-237.

[12] Gauthier-Maradei P., Tavera Ruiz C.P., Capron M. 2019. Oil and Aromatic Yield Maximization During Pyrolysis of Scrap Tire Rubber. Waste and Biomass Valorization, 10: 3723-3733.

[13] Ayanoğlu A., Yumrutaş R. 2016. Production of gasoline and diesel like fuels from waste tire oil by using catalytic pyrolysis. Energy, 103: 456-468.

[14] Alkhatib R., Loubar K., Awad S., Mounif E., Tazerout M. 2015. Effect of heating power on the scrap tires pyrolysis derived oil. J. Anal. Appl. Pyrolysis,116:10-17.

[15] Islam M.R., Parveen M., Hanı H., Sarker M.R.I. 2010. Innovation in Pyrolysis Technology for Management of Scrap Tire: a Solution of Energyand Environment. Int. J. Environ. Sci. Dev., 1:89-96.

[16] Ayanoglu A., Yumrutaş R. 2016. Rotary kiln and batch pyrolysis of waste tire to produce gasoline and diesel like fuels. Energy Convers. Manag, 111: 261-270.

[17] Wang W.C., Bai C.J., Lin C.T., Prakash S. 2016. Alternative fuel produced from thermal pyrolysis of waste tires and its use in a di diesel engine. Appl. Therm. Eng, 93: 330-338.

[18] Pedroso D.T., Kaltschmitt M. 2012. Dichrostachys cinerea as a possible energy crop-facts and figures. Biomass Convers. Biorefinery, 2: 41-51.

[19] Martínez J.D., Murillo R., García T., Veses A. 2013. Demonstration of the waste tire pyrolysis process on pilot scale in a continuous auger reactor. J. Hazard. Mater, 261: 637-645.

[20] Quek A., Balasubramanian R. 2013. Liquefaction of waste tires by pyrolysis for oil and chemicals - A review. J. Anal. Appl. Pyrolysis, 101: 1-16.

[21] Ilkiliç C., Aydin H. 2011. Fuel production from waste vehicle tires by catalytic pyrolysis and its application in a diesel engine. Fuel Process. Technol, 92: 1129-1135.

[22] Arpa O., Yumrutas R., Demirbas A. 2010. Production of diesel-like fuel from waste engine oil by pyrolitic distillation. Appl. Energy, 87: 122-127.

[23] Arpa O., Yumrutaş R., Argunhan Z. 2010. Experimental investigation of the effects of diesellike fuel obtained from waste lubrication oil on engine performance and exhaust emission. Fuel Process. Technol, 91: 1241-1249.

[24] Başgel S. 2012. Petrol kökenli yakıtlarda önemli ağır metallerin analizi ve porfirine bağlı vanadyum türünün tayini, Doktora Tezi, Fen Bilimleri Enstitüsü, İnönü Üniversitesi, Malatya.

[25] Tyler G. 2012. ICP Optical Emission Specroscopy Technical Note 05: ICP-OES , ICP-MS and AAS Techniques Compared. 1-11.

[26] Boryaev A.A. 2020. Development of advanced methods of determining the chemical stability of hydrocarbon fuels. Thermochim. Acta, 685: 178508.

[27] Kandala H. 2009. The Study of Variations in the Properties of Biodiesel on Addition of Antioxidants.

[28] Topa E.H. 2010. Thermal characterization and kinetics of diesel, methanol route biodiesel, canola oil and diesel-biodiesel blends at different blending rates by TGA and DSC, Doktora Tezi, Fen Bilimleri Enstitüsü, Orta Doğu Teknik Üniversitesi, Ankara.

[29] Dwivedi G., Sharma M.P. 2016. Experimental investigation on thermal stability of Pongamia Biodiesel by thermogravimetric analysis. Egypt. J. Pet,25:33-38.

[30] Cabral M.R.P., dos Santos S.A.L., StropaJ.M., da Silva R.C. d. L., Cardoso C.A.L., de Oliveira L.C.S., Scharf D.R., Simionatto E.L., Santiago E.F., Simionatto E. 2016. Chemical composition and thermal properties of methyl and ethyl esters prepared from Aleurites moluccanus (L.) Willd (Euphorbiaceae) nut oil. Ind. Crops Prod, 85:109-116.

[31] Zanier A., Jäckle H.W. 1996. Heat capacity measurements of petroleum fuels by modulated DSC. Thermochim. Acta, 287: 203-212.

[32] https://www.nonachem.com/turkish/hizmetlerimiz/akaryakitlar/dizel-mazot/index.php (Access date: 02.12 .2020$)$. 
[33] Taheri-Shakib J., Rajabi-Kochi M., Kazemzadeh E., Naderi H., Shekarifard A. 2018. A comprehensive study of the impact of wax compositions on the wax appearance temperature (WAT) of some Iranian crude oils: An experimental investigation. J. Pet. Sci. Eng, 165: 67-80.

[34] Coutinho J.A.P., Dauphin C., Daridon J.L. 2000. Measurements and modelling of wax formation in diesel fuels. Fuel, 79: 607-616.

[35] Miller S.J., Shah N., Huffman G.P. 2005. Conversion of waste plastic to lubricating base oil. Energy and Fuels, 19:1580-1586.

[36] Wong S.L., Ngadi N., Abdullah T.A.T., Inuwa I.M. 2015. Current state and future prospects of plastic waste as source of fuel: A review, 50:1167-1180.

[37] Kaimal V.K., Vijayabalan P. 2015. A detailed study of combustion characteristics of a DI diesel engine using waste plastic oil and its blends. Energy Convers. Manag, 105:951-956

[38] Lee S., Yoshida K., Yoshikawa K. 2015. Application of Waste Plastic Pyrolysis Oil in a Direct Injection Diesel Engine: For a Small Scale Non-Grid Electrification. Energy Environ. Res,5:18-

[39] Scheirs J.2006. Overview of Commercial Pyrolysis Processes for Waste Plastics. In: Feedstock Recycling and Pyrolysis of Waste Plastics: Converting Waste Plastics into Diesel and Other Fuels

[40] Veksha A., Giannis A., Chang V.W.C. 2017. Conversion of non-condensable pyrolysis gases from plastics into carbon nanomaterials: Effects of feedstock and temperature. J. Anal. Appl. Pyrolysis, 124:16-24.

[41] Boutekedjiret C., Bentahar F., Belabbes R., Bessiere J.M. 2003. Extraction of rosemary essential oil by steam distillation and hydrodistillation. Flavour Fragr. J. 18:481-484.

[42] Guo Z., Wang S., Gu Y., Xu G., Li X., Luo Z. 2010. Separation characteristics of biomass pyrolysis oil in molecular distillation. Sep. Purif. Technol,76:52-57.

[43] De Oliveira F.S., Teixeira L.S.G., Araujo M.C.U., Korn M. 2004. Screening analysis to detect adulterations in Brazilian gasoline samples using distillation curves. Fuel, 83:917-924.

[44] Sanchez-Minero F., Ancheyta J., Silva-Oliver G., Flores-Valle S. 2013. Predicting SARA composition of crude oil by means of NMR. Fuel, 110:318-321.

[45] Banar M., Akyildiz V., Özkan A., Çokaygil Z., Onay Ö. 2012. Characterization of pyrolytic oil obtained from pyrolysis of TDF (Tire Derived Fuel). Energy Convers. Manag,62:22-30.

[46] Takahashi J. 2013. Analysis of Trace Metallic Impurities in Hydrocarbon Fuels by ICP-MS Application note, https://www.agilent.com/cs/library/applications/5991-3264EN.pdf. (Access date: 02.12.2020).

[47] Forest, Ministry of Environment and, Regulation on Control of Waste Oils, Ankara, Turkey (2008).

[48] Atabani A.E., Mekaoussi M., Uguz G., Arpa O., Ayanoglu A., Shobana S. 2018. Evaluation, characterization, and engine performance of complementary fuel blends of butanol-biodieseldiesel from Aleurites moluccanus as potential alternative fuels for CI engines. Energy Environ, 0:1-30.

[49] Gouveia L., Oliveira A., Congestri R., Bruno L., Soares A.T., Menezes R.S., Antoniosi Filho N., Tzovenis I. 2017. Biodiesel from Microalgae. In: Microalgae-Based Biofuels and Bioproducts: From Feedstock Cultivation to End-Products, 235-258.

[50] Bennett, J. 2014. Advanced Fuel Additives for Modern Internal Combustion Engines. Altern. Fuels Adv. Veh. Technol. Improv. Environ. Perform. Towar. Zero Carbon Transp., 165-194

[51] Chen J., Li T., Han S. 2017. Impact on Diesel Fuel Crystallization of Alkyl-MethacrylateMaleic-Anhydride-Methacrylamide Terpolymers Used as Cold-Flow Improvers. Chem. Technol. Fuels Oils., 53: 436-443.

[52] Gonnet C., Morel D., Ramamonjinirina E., Serpinet J., Claudy P., Letoffé J.M. 1985. Insertion of Various Long Alkyl Chain Molecules in Brush-Type Grafted Monolayers: Chromatographic Study of the Resulting Materials. Journal of Chromatography A., 330: 227-241. 